\title{
MODERN TRENDS IN GOVERNANCE OF STATE OWNERSHIP RELATIONS
}

\author{
Iurii Umantsiv', Larysa Lebedeva ${ }^{2}$, Anastasiia Mytrofanova ${ }^{3}$
}

\begin{abstract}
Today, the diversity of functions of the state is objectively expanding, especially in the context of socially oriented economies of developed countries. Effective governance of state property serves as a solid foundation for successful performance of the state functions. The chosen topic is of particular relevance in the context of Ukraine's transformational economy. The subject of research is the system of economic relations of state property. Methodology. In the course of the study, a general philosophical dialectical method was used to find contradictions in the phenomena and sources of their development, such as the essence of state property and its contents. Common scientific methods were also used: analysis and synthesis; comparative analysis; statistical methods for calculating the structure and dynamics of indicators of condition and development of state property. The overall system for assessing the socio-economic efficiency of state property management was carried out on the basis of microeconomic indicators and macroeconomic indicators (indicators of economic and social efficiency). The purpose of the paper is to reveal the trends of development of state ownership relations in the European countries as well as in Ukraine, in particular, the difficulties of the process of managing them, as well as to formulate possible ways to overcome such difficulties. Conclusions of the study. Today, the importance of the state as a public institute is objectively increasing in the most economically developed countries. By succeeding in achieving positive institutional changes in ownership relations (creating favorable conditions for SMEs, developing market infrastructure, conducting moderate privatization of state property, transferring state-owned enterprises to market tracks, maintaining policies for protecting national interests, etc.) the grounds for economic growth and improvement of the social sphere in France and Poland were made. Though the conducted analysis showed that the development of state property in Ukraine is contradictory, it has the following problems: ambiguous character of privatization; low efficiency of state property governance; insufficient efficiency of work of enterprises with state ownership; institutional problems. Overall, the socio-economic efficiency of state property governance in Ukraine needs improvement. Thus, the state policy of property governance should include, in particular, the following steps: development of a national model of governance, as well as strategies for the development of state property; organization of state property management entities; development of a system of criteria and indicators for assessing not only the economic but also the social efficiency of state property governance.
\end{abstract}

Key words: state property, role of state in economy, state corporate rights, socio-economic efficiency, privatization.

JEL Classification: B52, H11, H82, P26

\section{Introduction}

The degree of participation of the state in the economic, social and humanitarian life of society throughout the history of mankind has gradually increased, while experiencing temporary fluctuations in the expansion and narrowing of the sphere of state responsibility. Economic thought, responding to the needs of economic reality, has given rise to two groups of schools in relation to government intervention in the economy. First, liberal schools that believe that natural market

\footnotetext{
Corresponding author:

${ }^{1}$ Kyiv National University of Trade and Economics, Ukraine.

E-mail: u.umantsiv@knute.edu.ua

ORCID: https://orcid.org/0000-0003-0788-7110

ResearcherID: N-7018-2016

${ }^{2}$ Kyiv National University of Trade and Economics, Ukraine.

E-mail:1.lebedeva@knute.edu.ua

ORCID: https://orcid.org/0000-0001-8632-5460

ResearcherID: O-2213-2016

${ }^{3}$ National Technical University "Kharkiv Polytechnic Institute", Ukraine.

E-mail: anastasia_mitrofanova@ukr.net

ORCID: https://orcid.org/0000-0002-5427-8927
} 
forces are capable of achieving economic equilibrium, therefore, the role of the state should be reduced to a "night watch" (classical school of political economy, marginalism, neoclassical school, modern neoliberal theories). Secondly, schools that believe that the market mechanism is incapable of self-regulation, so state regulation of economy is designed to compensate for the "fiasco of a market" (mercantilism, utopian socialism, Marxism, Keynesianism, institutional economics). During the twentieth century understanding of the role of the state in macroeconomic regulation fluctuated between two poles, which appeared in the alternation of periods of privatization, on the one hand, and nationalization, on the other hand.

Today, importance of the state as a public institute is objectively increasing in the most developed countries with a socially oriented market economy. State property management can be seen as one of the fundamental functions of the state in the process of institutional change. Problem with the state's fulfillment of this function is one of the factors that harden the flow of economic reforms in Ukraine in the transformation period, in particular, problems of privatization of state property, management of corporate rights of the state, the consequences of which are reflected in the current development of the domestic economy. Therefore, this topic of research is extremely relevant.

First of all, there is a need for a comprehensive approach that considers not only the corporate rights management of the state, which is a very common topic today, but also the problems of governance of state property. Researchers mainly focus on analyzing a number of microeconomic indicators of the quality of state property governance (Mukha, 2012) or assessing the quality of corporate governance (Popov, 2009; Fedorenko, 2014). While the analysis of macroeconomic indicators of social effectiveness of governance, as well as comprehensive studies of state property governance, as a rule, remain out of the scientists' attention.

Therefore, the purpose of the paper is to reveal the trends of development of state ownership relations in European countries as well as in Ukraine, in particular the difficulties of the process of managing them, as well as to formulate possible ways to overcome such difficulties. This purpose was achieved by using a general philosophical dialectical method to find contradictions in the phenomena and sources of their development, such as the essence of state property and its contents. Common scientific methods were also used: analysis and synthesis; comparative analysis; statistical methods for calculating the structure and dynamics of indicators of the state and development of state property; graphic modeling. The logic of the presentation of the material is as follows: in the beginning, reviews of recent publications on the subject is given, then the problems of development of state property in the EU (on the example of France and Poland) as well as in Ukraine are considered. The Discussion section offers an author's vision of how to solve the problems of governance of state property in Ukraine. Finally, the conclusions of the study are presented.

\section{Analysis of recent research and publications}

Governance of the state property relations is a complex issue that raises many cross-cutting problems that have been raised by different researchers. Thus, the current trends in the evolution of the property rights and their impact on economic development are examined in the works of V. Volchik (Volchik, 2014), M. Ticha (2009), A. Zawojska (Zawojska, 2013), L. Cviklova (Cviklova, 2016). Privatization processes and their contradictions in the transformational economy are analyzed in the works of O. Popov (Popov, 2009), M. Khokhlov (Khokhlov, 2008) and others. The research of corporate governance system of the state was made by R. Mukha (Mukha, 2012), O.Paskhaver (Paskhaver, 2008),A. Fedorenko (Fedorenko, 2014), Iu. Umantsiv, O. Ishchenko (Umantsiv, Iu., Ishchenko, O., 2017) and others. In the works of S. Lazzarini (Lazzarini, 2018), O.Tkachuk, V. Khachatryan, (Tkachuk, Khachatryan, 2019), V. V. Bokovets et al (Bokovets, Zamkova, Makhnachova, 2017) the effectiveness of state and private enterprises is compared. State and private property rights, their specification and erosion are discussed in the works of R. Shiryaeva (Shiryaeva, 2011), M. Justesen (Justesen, 2015).

\section{Presentation of the main material 3.1. Governance of state property in the countries of EU}

Today, the importance of the state as a public institute is objectively increasing in the most economically developed countries. State property governance can be seen as one of the fundamental functions of the state in the process of institutional change. France has an interesting experience of state involvement in shaping institutional ownership changes. This country is characterized by the most developed (of all Western European countries) state regulation of the economy, which is manifested in indicative planning (the formation of strategic plans and current forecasts is done by the General Commissariat for Planning).

The economy of France accumulates all forms of ownership today, such as: state, collective, individual, mixed. After large-scale nationalization (energy, coal, chemical industry, ferrous metallurgy, transport engineering, household electrical equipment production, construction, communication and transport, etc.) in the 1950's and 1960's a third of the property was owned by the state, including a fifth of the industry, banks, motor vehicles, major insurance companies and broadcasters. The main objective at this time was industrialization in order to maintain the 
status of a strong state in France. Accordingly, the public sector made $30 \%$ of all investments.

After two waves of denationalization, which took place in the 1970s and 1990s, many industrial enterprises and banks remained in the public sector. But the mechanism for managing them has changed significantly. SOEs have been transformed into joint-stock companies (stateowned majority in shares), and transferred to a budgetindependent operation.

In the XXI century the country's policy is aimed at further developing the competition that underpins free enterprise and trade. Accordingly, the creation of small businesses is constantly stimulated by various types of assistance in obtaining long-term and short-term loans, providing tax benefits, guarantees and credit insurance, providing commercial information, establishing legal guarantees to prevent complete bankruptcy, the selection of specialists to coordinate the activities of small businesses.

Today, the state policy is aimed at further socializing the property institute. Thus, in France, the internal redistribution of shares is legislatively stimulated. The tendency for companies to become fully owned by their staff is becoming more prominent. In essence, it is a matter of creating a cooperative form of ownership not through the merger of small individual owners, but through the acquisition of the enterprise by its staff. Thus, France has a formative influence on the property institute through methods of state regulation, in particular by stimulating entrepreneurial activity, creating conditions for further cooperation and so on.

Poland's practice of shaping institutional ownership changes is particularly valuable to Ukraine. After all, this country is close to Ukraine both in the tradition of organizing the socio-economic sphere (in the historical aspect of socialist living conditions with all the original components), and in geographical location.

Prior to the reforms (1990), Poland's economy was in a state of deep systemic economic crisis (hyperinflation, declining production levels, and living standards). Accordingly, a course was laid on cardinal systemic changes, which were then called "shock therapy". The following measures have been taken to ensure stabilization: strict monetary policy; elimination of the budget deficit by reducing subsidies for food, raw materials, energy industry, abolition of most tax benefits; liberalization of prices except for energy, transport tariffs, rent, medicines; introduction of partial conversion of currency of Poland in the conditions of its considerable devaluation, unification of the exchange rate in all markets and liberalization of foreign trade; rigid restrictive income policy.

But "shock therapy" was criticized by the political elite of Poland, and in 1994-1997 a successful program of gradualist reforms was introduced with the Strategy for Poland, which was fundamentally different from the previous liberal policy of reforms. The key vectors were the following: creation of necessary institutions, state intervention in the economy, fair distribution of income. The country's major macroeconomic indicators have been significantly improved during the reforms.

Between 1990 and 1992, the so-called "small-scale privatization" took place in Poland, with the large share of retail and consumer services transferred into private hands. The share of the private sector in GDP has increased from $29 \%$ in 1989 to $47 \%$ in 1992, and reached almost $70 \%$ in 1996. As for the privatization of large enterprises, the government was in no hurry, because it understood the importance of gradual changes in the principles of their management. In other words, the Strategy for Poland program was based not on the destruction of the public sector, but on the gradual privatization. Correspondingly, the corporatization of state-owned enterprises with a limited number of shareholders and the transition to management through the hiring of competent managers has been done (Palekhova, 2008).

Thus, state-owned enterprises mostly operate with the participation of private capital and are organizations over which the state exercises control to achieve the set objectives with maximum efficiency. At the same time, in strategic enterprises, especially in the sphere of energy and heavy industry, the state retained a controlling stake, and for better capital rising, some of the shares are quoted on the stock exchange. This applies, for example, to the Polish energy group or to other energy companies. As of 2015, the state retained a minority stake in 346 enterprises and a majority stake in 47 . Thus, in 2015, the annual dividend income exceeded the profit from the sale of enterprises by 10 times, reaching the level of 45 billion zlotys ( $\$ 12$ billion) (Belas, 2016).

Thanks to the creation of large and export-oriented small and medium-sized enterprises in the years of transformation to market economy, Poland has managed to overcome the crisis in industrial production quite quickly (2008 - 2009). During the financial crisis, SMEs were supported and stimulated by the significant expansion of the bank guarantee system and facilitated access to EU funds.

Thus, by succeeding in achieving positive institutional changes in ownership relations (creating favorable conditions for SMEs, developing market infrastructure, conducting moderate privatization of state property, transferring state-owned enterprises to market tracks, etc.) the grounds for economic growth and improvement of the social sphere in the country were made.

\subsection{The problems of governance of state property in Ukraine}

The place of state property in modern economic systems is primarily determined by its central role as a basis for state to fulfill its functions. In our view, the quality of these functions implementation is possible only under the condition of adequate development of state property relations. 
According to the Law of Ukraine "On Managing Objects That Are in State Ownership" (Article 1), the process of governance of state property is exercised by the Cabinet of Ministers of Ukraine. The state property may include natural resources, basic means of production in all sectors of the economy, financial resources, gold and foreign exchange reserves, as well as cultural values. State corporate rights are a particular subject of governance. According to the Resolution of the Cabinet of Ministers of Ukraine "On Approving Basic Conceptual Approaches to Improving the Effectiveness of Corporate Governance of the State", the state corporate rights (CSR) are determined by the state's share in the capital of a company, and include the right to manage such a company, gain profit (dividends), and the distribution of assets in the event of liquidation.

In Ukraine, the development of state property, especially in the course and in the wake of the economic reforms of the 1990s, is very controversial. Let us distinguish the following problems of development of state property in Ukraine:

1) the nature of privatization and its results;

2) problems of efficiency of governance of state property and state corporate rights;

3) problems of state-owned enterprises as separate economic units;

4) blurring of state and private property rights;

5) interconnections between "ownership-power" relations.

\subsubsection{The nature of privatization and its results}

Large-scale privatization of state-owned property was the basis of economic downturn in the process of transformation of the economic system of Ukraine. In 1992, the Verkhovna Rada adopted the Laws of Ukraine "On Privatization of Small State Enterprises (Small Privatization)", "On Privatization Papers", "On Privatization of State Housing Fund". To ensure the implementation of the legislative norms, a special body of executive power - the State Property Fund of Ukraine was created. Since 1992, the State Privatization Programs have been approved annually by the Verkhovna Rada, which contain the conditions, plans and organizational measures for privatization for a year.

The First State Privatization Program identified the following strategic goals of this process: the creation of a layer of non-state owners as the basis of a multifaceted economy; increasing the efficiency of production facilities; development of competitive environment and restriction of monopolies; attraction of foreign investments. Thus, privatization process was entrusted with the fundamental tasks of developing private ownership and stimulating private initiative in the process of market transformations. In addition, its fiscal function on filling the revenue part of the state budget was recognized as important.
During the first decade of privatization process, the share of state property in fixed assets in Ukraine decreased from $81.3 \%$ to $56.7 \%$, and the share of public sector employees fell from $78.7 \%$ to $35.5 \%$. Trade and public catering, household services, light and food industry developed rapidly. In many industries, with the exception of electricity, fuel, milling, the private sector prevailed. The majority of industrial products $(63.6 \%)$ were produced by non-state enterprises.

However, unfortunately, not all objectives have been successfully achieved, as the privatization process has encountered some difficulties, such as the lack of a clear strategy; inefficient use of received funds; insufficient legislative support; shadow privatization; the practice of bringing businesses into bankruptcy in order to rebuy them.

\subsubsection{Problems of efficiency of governance of state property and state corporate rights}

It is important to analyze the effectiveness of the process of governance of state property. Assessing governance effectiveness involves having a set of metrics that have not been created yet. Researchers (Solovjan, 2011; Fedorenko, 2014) often propose a solution to this problem through the use of fairly traditional indicators, rather than creating the system of indicators aimed specifically at assessing the governance of state property. In addition, as a rule, they tend to evaluate the economic efficiency itself rather than the socio-economic or social management effectiveness. In particular, following indicators are used: annual profitability of corporate rights; return on assets, sales, net profit.

If we try to give a general quantitative description of the state property governance process carried out by the State Property Fund of Ukraine (SPFU), we will see that, according to the Fund (State Property Fund of Ukraine, 2019), it transferred UAH 5.362 billion to the State budget in 2017, and UAH 0.25 billion was received for the fulfillment of its tasks. That is, as a result of the governance activity of the Fund, the state received a net income of UAH 5.112 billion. However, if we consider the structure of this income, it turns out that $62.9 \%$ was obtained through the privatization of state property; $19.7 \%$ at the expense ofleasing of state property; $17.3 \%$ due to dividend income and net income. Thus, most of the proceeds from the governance of state-owned property are short-term revenues, which cannot be planned as a basis for economic growth of the country. At the same time, regular revenues from state-owned enterprises, dividends and rents, which can be used for long-term budget planning, account for much less of the revenue.

Let us formulate the general system of indicators for assessing not only the economic efficiency, as it is most often done, but also the socio-economic efficiency of governance of state property, in particular of corporate state rights in state-owned companies (see Table 1). 
Vol. 5, No. 5, 2019

Table 1

A system of indicators for assessing the effectiveness of state property governance, in particular corporate state rights

\begin{tabular}{|c|c|c|}
\hline Group & Indices & Essence \\
\hline 1 & 2 & 3 \\
\hline \multicolumn{3}{|c|}{ Microeconomic indicators, including: } \\
\hline $\begin{array}{l}\text { indicators of economic } \\
\text { efficiency and financial } \\
\text { sustainability }\end{array}$ & $\begin{array}{l}\text { - labor productivity, capital productivity, capital intensity, material } \\
\text { efficiency, material intensity, capital stock at the enterprise; } \\
\text { - profitable amount of assets for sale; } \\
\text { - net profit in the share capital; } \\
\text { - revenue from fixed assets, number of employees. }\end{array}$ & $\begin{array}{l}\text { characterize the economic efficiency } \\
\text { and financial sustainability of the } \\
\text { functioning of state-owned enterprises } \\
\text { or state-owned enterprises }\end{array}$ \\
\hline dividend policy indicators & $\begin{array}{l}\text { - stock price dynamics; } \\
\text { - ratio of the share price to its nominal value; } \\
\text { - volume and dynamics of dividend payments; } \\
\text { - dividend per share in circulation; } \\
\text { - net profit per share in circulation; } \\
\text { - share of net profit paid as dividend; } \\
\text { - the ratio of dividends to the share price (return on equity) }\end{array}$ & $\begin{array}{l}\text { characterize the state's income from } \\
\text { corporate rights in (public) open joint- } \\
\text { stock companies }\end{array}$ \\
\hline $\begin{array}{l}\text { indicators of quality } \\
\text { assessment of corporate } \\
\text { governance }\end{array}$ & $\begin{array}{l}\text { - fulfillment of the financial plan of the enterprise in terms of } \\
\text { revenue from sales of products, net profit, transfer of net profit to } \\
\text { the budget; } \\
\text { - fulfillment of agreement conditions }\end{array}$ & $\begin{array}{l}\text { characterize the quality of corporate } \\
\text { governance of heads of state-owned } \\
\text { enterprises or representatives of the } \\
\text { state in governing bodies of commercial } \\
\text { companies }\end{array}$ \\
\hline \multicolumn{3}{|c|}{ Macroeconomic indicators, including: } \\
\hline cost-effectiveness indicators & $\begin{array}{l}\text { - volume and dynamics of deduction of profit (dividends) to budgets; } \\
\text { - total annual profitability of corporate rights } \\
\text { - efficiency of use of resources: productivity of labor, capital } \\
\text { productivity, capital intensity, material efficiency, material } \\
\text { intensity, capital stock of labor in the public sector; } \\
\text { - number of enterprises in the process of bankruptcy. } \\
\text { - innovation expanses (financed from the state budget) }\end{array}$ & $\begin{array}{l}\text { characterize the economic efficiency of } \\
\text { the public sector as a macroeconomic } \\
\text { entity }\end{array}$ \\
\hline $\begin{array}{l}\text { social performance } \\
\text { indicators }\end{array}$ & $\begin{array}{l}\text { - level and dynamics of wages in the public sector; } \\
\text { - employment of socially disadvantaged sections of the population; } \\
\text { - maintenance of social infrastructure facilities; } \\
\text { - level of prices for products; } \\
\text { - participation of businesses in government programs, including } \\
\text { social programs }\end{array}$ & $\begin{array}{l}\text { characterize the quality of the } \\
\text { performance of social functions of the } \\
\text { state using state property }\end{array}$ \\
\hline
\end{tabular}

Source: made by the authors

Researchers (Mukha, 2012; Solovjan, 2011) often concentrate on calculations and analysis of a group of microeconomic indicators of economic efficiency of governance of state-owned enterprises; examine the financial position and dividend policy of individual entities selected for analysis. However, the analysis of macroeconomic indicators of economic and social efficiency of state property governance, as a rule, either is not conducted at all or is not carried out in sufficient volume. Let us calculate and analyze selected macroeconomic indicators of economic efficiency of state property governance (see Table 2) for the period of 2010-2017 in Ukraine.

The total annual yield on corporate rights in state owned companies is low, fluctuating from year to year, and has a general tendency to decrease. During this period, the absolute number of entities at different stages of bankruptcy (property disposal, liquidation) decreased significantly; a similar trend is observed with regard to the share of enterprises in the process of bankruptcy in the total number of enterprises managed by SPFU. Expenditures on innovation activities (financed from the state budget) have unstable values and fluctuate from year to year, but the percentage is quite low (from $0.4 \%$ to $4.47 \%$ ).

In our view, among the indicators of social efficiency, one of the most important is the wages in traditional sectors of the public sector compared to other sectors and to the national average in general (see Table 3 ).

As we can see from the table, the wages in the traditional public sectors exceeded the average in Ukraine only in the sphere of public administration, as well as defense, social insurance by 1.1-1.4 times, with trends in 20162018 indicating further increase of this indicator. However, at the same time, in those areas that reflect the state's fulfillment of basic social functions, i.e. in the field of education, health care, social assistance, functioning of cultural institutions, there is a steady tendency to lag behind the national average wage. Thus, in the field of education, such a gap is $16-27 \%$; in the health and social 
Table 2

Macroeconomic indicators of economic efficiency of public property governance

\begin{tabular}{|c|c|c|c|c|}
\hline \multirow{2}{*}{ Year } & \multicolumn{4}{|c|}{ Indices } \\
\cline { 2 - 5 } & $\begin{array}{c}\text { Total annual yield } \\
\text { on corporate rights, UAH }\end{array}$ & $\begin{array}{c}\text { Resource efficiency: } \\
\text { labor productivity } \\
\text { in the public sector, UAH } \\
\text { process of bankruptcy, units } \\
\text { / share of bankruptcies in the } \\
\text { total number of enterprises } \\
\text { managed by SPFU, }\end{array}$ & $\begin{array}{c}\text { Innovation expanses } \\
\text { (financed from the } \\
\text { state budget, } \% \text { of total } \\
\text { expenditures) }\end{array}$ \\
\hline 2010 & $\mathrm{n} / \mathrm{d}$ & 1.66 & $158 / \mathrm{n} / \mathrm{d}$ & 1.08 \\
\hline 2011 & 0.019 & 1.61 & $128 / 26$ & 1.04 \\
\hline 2012 & 0.018 & 1.61 & $121 / 24.9$ & 1.95 \\
\hline 2013 & 0.004 & 1.57 & $65 / 17.3$ & 0.26 \\
\hline 2014 & 0.008 & 1.64 & $63 / 16.9$ & 0.47 \\
\hline 2015 & 0.004 & 1.76 & $55 / 15.4$ & 0.77 \\
\hline 2016 & 0.011 & 1.74 & $55 / 16.1$ & 2.49 \\
\hline 2017 & 0.003 & $\mathrm{n} / \mathrm{d}$ & & \\
\hline
\end{tabular}

Source: calculated by authors based on (Mytrofanova and Reshetnjak, 2019; Fedorenko, 2014)

Table 3

Wages in traditional public sector compared to the average in Ukraine

\begin{tabular}{|c|c|c|c|c|c|c|c|c|c|}
\hline \multirow[t]{2}{*}{ Years } & \multirow{2}{*}{$\begin{array}{c}\text { Average } \\
\text { salary, UAH. }\end{array}$} & \multicolumn{2}{|c|}{$\begin{array}{c}\text { Salary; government, } \\
\text { defense, social insurance }\end{array}$} & \multicolumn{2}{|c|}{ Salary; education } & \multicolumn{2}{|c|}{$\begin{array}{l}\text { Salary; health care } \\
\text { and social assistance }\end{array}$} & \multicolumn{2}{|c|}{$\begin{array}{l}\text { Salary; functioning } \\
\text { of libraries, archives, } \\
\text { museums and other } \\
\text { cultural institutions }\end{array}$} \\
\hline & & UAH & $\begin{array}{l}\text { relative to } \\
\text { the average } \\
\text { wage }\end{array}$ & UAH & $\begin{array}{c}\text { relative to } \\
\text { the average } \\
\text { wage }\end{array}$ & UAH & $\begin{array}{c}\text { relative to } \\
\text { the average } \\
\text { wage }\end{array}$ & $\mathrm{UAH}$ & $\begin{array}{c}\text { relative to } \\
\text { the average } \\
\text { wage }\end{array}$ \\
\hline 2010 & 2250 & 2735 & 1.22 & 1884 & 0.84 & 1616 & 0.72 & 1912 & 0.85 \\
\hline 2011 & 2648 & 3049 & 1.15 & 2077 & 0.78 & 1762 & 0.67 & 2124 & 0.80 \\
\hline 2012 & 3041 & 3432 & 1.13 & 2532 & 0.83 & 2186 & 0.72 & 2579 & 0.85 \\
\hline 2013 & 3282 & 3719 & 1.13 & 2696 & 0.82 & 2351 & 0.72 & 2737 & 0.83 \\
\hline 2014 & 3480 & 3817 & 1.10 & 2745 & 0.79 & 2441 & 0.70 & 2769 & 0.80 \\
\hline 2015 & 4195 & 4381 & 1.04 & 3132 & 0.75 & 2829 & 0.67 & 3049 & 0.73 \\
\hline 2016 & 5183 & 5953 & 1.15 & 3769 & 0.73 & 3400 & 0.66 & 3705 & 0.71 \\
\hline 2017 & 7104 & 9372 & 1.32 & 5857 & 0.82 & 4977 & 0.70 & 5464 & 0.77 \\
\hline 2018 & 8865 & 12698 & 1.43 & 7041 & 0.79 & 5853 & 0.66 & 6381 & 0.72 \\
\hline
\end{tabular}

Source: calculated by the authors based on (Report on the work of the State Property Fund of Ukraine and the progress of privatization of state property in 2017, 2018)

care sectors it is $28-34 \%$; in the functioning of cultural institutions it is $15-29 \%$. At the same time, in 2018, wages in the wholesale and retail trade area were by 1.1 times higher than the national average; in the field of information and telecommunications by 1.6 times; in the field of financial and insurance activities by 1.8 times.

It should be emphasized that the State Property Fund applies its own methodology for assessing the quality of governance, which focuses on subjective factors and consists of assessing the quality of managerial functions performed by government representatives in joint stock companies. As a result, the SPFU concluded that management effectiveness remains poor. Thus, only $11 \%$ of companies demonstrate high efficiency in management; $14 \%$ of companies showed a satisfactory level; and the vast majority $-75 \%$ of the companies were found to be ineffective in terms of the management quality (Fedorenko, 2014).
The reasons for this unsatisfactory condition lie in the following problems of governance of state property, namely: a) a lack of a strategy for governance of state property in general and state corporate rights in particular; b) a complex system of public authorities responsible for corporate governance; c) low professional level, interest and responsibility of authorized bodies in the management process; d) conflict of regulatory and managerial functions of the state; e) unfavorable structure of corporate rights (Mytrofanova and Reshetnjak, 2019).

\subsubsection{Problems of functioning of state-owned enterprises}

In our view, the problems faced by state-owned enterprises in the course of their activity can be considered at several levels. At a micro level, there is a lack of resources for technological upgrade of 
production, significant depreciation of fixed assets, low degree of financial stability and liquidity. In the case of non-natural monopolies, there are difficulties in competing in the industry, including trade and online services (Gorodnichenko et al., 2018), and the difficulty of finding competitive advantages (Gerasymenko et al. , 2017). Macro-level enterprises of any form of ownership are in one way or another confronted with the unpredictable economic policies of the state, that are often influenced by political cycles and demands of the international financial institutions. In addition, the overall macroeconomic conditions in the country are rather unfavorable, as Ukraine experienced several major economic crises during the years of independence (1990s, 2008-2009, 2014-2015), which have led to decline in domestic demand, the outflow of staff, the rise in the cost of credit and more. At the global level, the intensification of competition (Nwabueze and Mileski, 2018), political upheavals, and the absence of sufficiently large world-class monopolies to compete effectively with the world's leading companies in the world markets are significant obstacles.

\subsubsection{Blurring of state and private property rights}

Institutional theory of property rights implies the need for a clear specification of property rights to ensure the effective functioning of property relations. Otherwise, the erosion of property rights opens up opportunities for protection problems and opportunistic behavior. Insufficient regulation of property rights is common in post-socialist countries, including Ukraine, as a result of radical market reforms, rapid privatization processes, and the lack of prompt construction of the institutional foundations of the new economic system. As a consequence the lack of specification in property rights is expressed in two sectors. Firstly, in the sphere of modern functioning of the state property itself. Here, according to research (Shirjaeva, 2011), there are many problems due to the fact of ownership by civil servants of unregistered property that can be used to pursue their own interests. Such abuses may be linked to the establishment of monopoly prices for goods and services of natural monopolies (tariffs for rail transport, gas prices, etc.); to public procurement at inflated prices; to direct distribution of state property or use for their own purposes.

Secondly, in the area of the connections between private and public property, that have been linked to privatization processes historically. In this case, the lack of transparency of privatization procedures raises the question of the initial legitimacy of the transfer of certain objects (including strategic ones) into private or joint-stock ownership. Moreover, such processes continue today. For example, privatization plans for
2018 (Analytical note on the work of the State Property Fund of Ukraine and the course of privatization of state property for 9 months of 2018, 2018) included such companies as Turbo-atom, President-Hotel, Mykolaivoblenergo, which are in the list of ten enterprises-leaders in terms of dividend payments to the State Budget. At the same time, privatization has traditionally featured the sale of unprofitable enterprises with the aim of improving state finances and transferring such enterprises to a more efficient owner. In addition, privatization plans include entities that have been previously listed as entities that cannot be objects of privatization. Moreover, these enterprises have a monopoly position or are of strategic importance for economy of the country. Preparations for the sale of these assets in accordance with the SPFU Report (State Property Fund of Ukraine, 2018) were made only after they have been excluded from the non-privatization list.

On the other hand, if it is proven that certain businesses were acquired unlawfully, re-nationalization of them, even with compensation for the owners, will lead to the phenomenon of "erosion of property rights", when the right of private ownership is not protected. Therefore, neither national nor foreign investors will be interested in investing without being confident in the sound protection of their rights. Unfortunately, in Ukraine in the 2000s the term of "re-privatization" came into existence, i.e. the return of privately owned enterprises back to the state, which at one time led to chaos with the determination of property rights for some objects.

\subsubsection{Interconnections between "ownership-power" relations}

By definition, the historical phenomenon of interconnections between "ownership-power" relations is the following: "Power (ownership) gives rise to the concept of property; property is born as a function of possession and power. Ownershippower is an alternative to the European antique, feudal and bourgeois private property in the non-European structures" (Vasilev, 1993). It is emphasized that the phenomenon of interconnections between "ownershippower" relations can be viewed in two respects: as a distinctive feature of non-European societies, and as a characteristic feature of the senatorial-vassal relations in the era of the European Middle Ages (Cirel, 2006). Historically, this phenomenon has appeared in the period of Kievan Rus and the Moscow state. A distinctive feature of this phenomenon is the primacy of power over property, i.e. a high status in the social hierarchy, due to the occupation of a certain position in the civil service, becomes a prerequisite for owning wealth. Moreover, since property depends on the authority, in the event of termination of civil service, private ownership of the wealth acquired is not guaranteed. 
It is difficult to say whether this phenomenon, which is actually spreading today in Ukraine, is caused by history itself. Probably it is not. More probable reasons are the lack of specification of state and private property rights, the lack of separation of state power from business, the availability of opportunities for abuse, corruption factors. As a result, an appointment of certain persons to higher governmental posts is made not by their objective abilities and knowledge, but by the large private property ownership. Property and power are mutually conditioned and merged. A closed circle of "property-power" connections is formed then, which may be interrupted by the coming to power of new elites, when both property and power are redistributed, and previous decision-makers often lose everything.

\section{Discussion}

The problems in the field of state property development in Ukraine need a dynamic and highquality solution. Thus, in the sphere of privatization processes, it is necessary to harmonize the policy of privatization of state-owned enterprises with the longterm goals of governing of state property; determine the scientifically sound amount of state property and consolidate it legally. It is necessary either to ensure the stability of the list of strategic state-owned objects that are not subject to privatization, or to reform the procedure for excluding companies from this list, to ensure its transparency and purposefulness, to eliminate the corruption component; to stop the privatization of really profitable enterprises. The fiscal function of privatization should play a subordinate role in relation to the function of improving the efficiency of public property management.

Among scholars (Mukha, 2012; Solovjan, 2011; Fedorenko, 2014), the "market", "competitivecentric" approach to solving problems of the system of governance of state property and in particular state corporate rights is dominant. The essence of this approach lies in recognizing the primacy of economic efficiency over social. In particular, it is proposed to optimize the number of state-owned enterprises; to improve the structure of their efficiency by exempting the state from the management of small blocks of shares amounting to $25 \%$; to transfer a part of the state's stake in the trust administration. It is also proposed to abolish the rule on the mandatory deduction of part of the net profit of the state-owned enterprise into the state budget. The idea is to allow the sale of part of the shares of state-owned joint-stock companies with $100 \%$ state ownership in order to attract additional investments.

Of course, an unbiased analysis, inventory of existing state property, in particular, its efficiency is necessary. Considering the specifics of the industries in which state-owned enterprises operate (education, health care, defense, economic security, strategic industries, natural monopolies, public goods), it may be inevitable that unprofitability (or subsidy) occur. In other words, reduced economic efficiency is a "pay" for social efficiency.

Therefore, it is necessary to radically change the very approach to assessing the performance of state-owned enterprises, and accordingly the process of managing them - from a purely "market" to one that takes into account the degree of fulfillment of their state functions, i.e., including the social component. Under these conditions, social performance indicators (see Table 1) should be included in the system of performance indicators for state property governance; otherwise, the objectives of the analysis and the method of evaluating results will not be consistent with each other.

In our opinion, problems in the process of public corporate governance in Ukraine can be solved using the following measures: a) streamlining the composition and functions of the entities managing the efficiency state corporate rights; b) creation of a domestic corporate model in the field of state corporate rights governance, taking into account foreign experience and national peculiarities; c) development of the State Efficiency Management Program of state corporate rights and strategic planning to improve the quality of management in this field in the short and long run; d) drafting of the Law of Ukraine "On Corporate Rights of the State", which should regulate relations in this sphere and protect the interests of the state; e) open the State Agency of Ukraine in management of state corporate rights and property, the regulations of which have been developed but are not yet in force; e) amend the Law of Ukraine "On Civil Service" with respect to raising the requirements for the quality of work of civil servants, as well as establishing the responsibility for their activities (Mytrofanova and Reshetnjak, 2019).

Institutional problems of eroding state and private property rights, as well as the existence of interconnections between "ownership-power" relations, in our view, are extremely difficult to solve, as they concern not only purely economic sphere but also established forms of behavior, informal rules that have become traditional over the last few decades and are difficult to influence. At the same time, it is necessary to try to include the specified institutional component in the state policy of governance of property relations. The current situation requires an increase in the degree of protection and specification of public and private property rights, ensuring the inviolability of both private and public property rights. The key to this is not only to improve legislation, but also to increase confidence in the country's law enforcement and judicial systems. It is necessary to amend the Law of Ukraine "On Civil Service" to strengthen the accountability of civil servants for making decisions related to the disposal of state property. It is necessary to ensure that the legislation regulates actions of the bureaucratic 
apparatus regarding the disposal of such objects. The role of civil society representatives in preventing the "conflict of interest" concerning state property objects should be strengthened.

\section{Conclusion}

Today, the importance of the state as a public institute is objectively increasing in the most economically developed countries. By succeeding in achieving positive institutional changes in ownership relations (creating favorable conditions for SMEs, developing market infrastructure, conducting moderate privatization of state property, transferring state-owned enterprises to market tracks, creating, policies for protecting national interests, etc.) the grounds for economic growth and improvement of the social sphere in France and Poland were made.

According to the results of this study, development of state property in Ukraine is characterized by the following problems: supremely sensitive nature of privatization; low efficiency of governance of state property and state corporate rights; insufficient efficiency of functioning of state-owned enterprises as separate economic units; institutional problems such as an erosion of state and private property rights and interconnections between "ownership-power" relations.

In our view, general system for assessing the socioeconomic efficiency of state property governance should include the following indicators: microeconomic indicators (indicators of economic efficiency and financial sustainability, dividend policy, quality assessment of corporate governance); macroeconomic indicators (indicators of economic efficiency and social effectiveness). Analysis of selected macroeconomic indicators of economic efficiency of public property governance in 2010-2017 in Ukraine showed that the annual yield of corporate rights of the state is low and tends to decline; the number of enterprises in the bankruptcy procedure has significantly decreased. As an indicator of social efficiency wages in the public sector in comparison with the average in Ukraine were taken, that are low with a tendency to decrease. Overall, the socioeconomic efficiency of public property governance in Ukraine needs improvement.

The ways to solve problems in the sphere of state property governance in Ukraine, in our opinion, lie, firstly, in strengthening the strategic thinking in the centers of decision-making, in avoiding situational ill-considered steps. Secondly, it is necessary to streamline the list and functions of controlling bodies in order to eliminate duplication of their functions. Thirdly, in the process of analyzing the effectiveness of state property governance, it is necessary to strengthen the social component. Fourth, it is necessary to include an institutional component in the state policy for managing the relations of state property in order to solve problems of erosion of state and private property rights, as well as the interconnections between "ownership-power" relations.

The subject of further research in the outlined direction may be a more detailed analysis of the social efficiency of public property governance using above mentioned indicators (see table 1), formation of additional indicators, as well as development of directions for improving such efficiency. In addition, a promising direction is a detailed analysis of implementation of social functions of the state through the governance of state corporate rights.

\section{Acknowledgements}

This article was prepared and funded within the research topic "The conceptual and paradigm shifts in economics of XXI century” reg. № 0118 U000126 of Economics and Competitive Policy department of Kyiv National University of Trade and Economics.

\section{References:}

Analitychna dovidka pro robotu Fondu derzhavnogho majna Ukrajiny ta khid pryvatyzaciji derzhavnogho majna za 9 misjaciv 2018 roku (2018). [Analytical note on the work of the State Property Fund of Ukraine and the course of privatization of state property for 9 months of 2018]. Kyiv: SPFU. (in Ukrainian)

Belas, M. (2016). Yak vidbuvalasya pryvatyzatsiya derzhavnykh pidpryyemstv u Pol'shchi [How the privatization of stateowned enterprises in Poland was made?]. Yevropeyska Pravda. Retrieved from: https://www.eurointegration.com.ua/ articles/2016/05/30/7049990/ (accessed 29 October 2019).

Bokovets, V. V., Zamkova, N. L., \& Makhnachova, N. M. (2017). Assessment of the effectiveness of enterprise management components in modern conditions. Scientific Bulletin of Polissia, 4, 27-32.

Cirel, S. V. (2006). «Vlast-sobstvennost» v trudah rossijskih istorikov i jekonomistov [«Power-ownership» in the writings of Russian historians and economists]. Obshhestvennye nauki i sovremennost, 3, 119-131.

Coibion, O. \& Gorodnichenko, Y. (2015). Information Rigidity and the Expectations Formation Process: A Simple Framework and New Facts. American Economic Review, 105, 2644-2678. doi: https://doi.org/10.1257/ aer.20110306

Cviklova, L. (2016). Evolution of Property Rights System in East and Central Europe Through Institutional Perspective. Proceedings from: The 3rd International Multidisciplinary Scientific Conference on Social Sciences and Arts. Vienna, Austria. Retrieved from: https://sgemsocial.org/ssgemlib/spip.php?article3309 (accessed 29 October 2019). 
Fedorenko, A. V. (2014). Upravlinnja derzhavnymy korporatyvnymy pravamy [Management of state corporate rights]. Ekonomika i proghnozuvannja, 4, 23-37. (in Ukrainian)

Gerasymenko, A., Borovyk, I., \& Afendikova, S. (2017). The methodology of competition assessment. Economic Annals-XXI, 5-6(165), 52-55. doi: https://doi.org/10.21003/ea.V165-11

Gorodnichenko, Y., Sheremirov, V., \& Talavera, O. (2018). Price Setting in Online Markets: Does IT Click? Journal of European Economic Association, 16(6), 1764-1811.

Justesen, M. K. (2015). Making and Breaking Property Rights: Coalitions, Veto Players, and the Institutional Foundation of Markets. Journal of Institutional and Theoretical Economics, 171(2), 238-262. doi: https://doi.org/ 10.1628/093245615X14273596658928

Khokhlov, M. P. (2008). Osnovy ekonomiky rozderzhavlennja i pryvatyzaciji [Fundamentals of the economy of privatization and privatization]. Kharkiv: Vyd. KhNEU. (in Ukrainian)

Lazzarini, S. G., \& Musacchio, A. (2018). State Ownership Reinvented? Explaining Performance Differences Between State-owned and Private Firms. Corporate Governance - An International Review, 26(4), $255-272$. doi: https://doi.org/10.1111/corg.12239

Mayster, A. (2014). Efektyvne upravlinnja derzhavnymy korporatyvnymy pravamy v Ukrajini: problemy ta shljakhy vyrishennja [Effective management of state corporate rights in Ukraine: problems and solutions]. Rynok cinnykh paperiv Ukrajiny, 1-2, 47-54. (in Ukrainian)

Mukha, R.A. (2012). Upravlinnja derzhavnymy korporatyvnymy pravamy v ghospodarsjkykh tovarystvakh: avtoreferat dysertaciji na zdobuttja naukovogho stupenja kandydata ekonomichnykh nauk [Management of State Corporate Rights in Business: Abstract of the Thesis for the Candidate's Degree in Economic Sciences]. Rivne: Nac. un-t vod. ghosp-va ta pryrodokorystuvannja). (in Ukrainian)

Mytrofanova, A. S., \& Reshetnjak, N. B. (2019). Osoblyvosti systemy upravlinnja korporatyvnymy pravamy derzhavy $\mathrm{v}$ Ukrajini [Features of the system of management of corporate rights of the state in Ukraine]. Biznes Inform, 3, 63-68. doi: https://doi.org/10.32983/2222-4459-2019-3-63-68 (in Ukrainian)

Nwabueze, U., \& Mileski, J. (2018). Achieving competitive advantage through effective communication in a global environment. Journal of International Studies, 11(1), 50-66. doi: https://doi.org/10.14254/2071-8330.2018/11-1/4 Palekhova, V. A. (2008). Polskyy dosvid perekhodu do rynku: uroky dlya Ukrayiny [Polish experience of transition to the market: lessons for Ukraine]. Istorychnyy arkhiv. Naukovi studiyi: Zb. nauk. pr., 2, 62-72. (in Ukrainian)

Paskhaver, O. J. (2008). Upravlinnja derzhavnoju vlasnistju $v$ Ukrajini: analiz i rekomendaciji $z$ udoskonalennja [State Property Management in Ukraine: Analysis and Recommendations for Improvement]. Kyiv. (in Ukrainian) Popov, O. Je. (2009). Teoretyko-metodologhichni ta konceptualjni zasady formuvannja orghanizacijno-ekonomichnogho mekhanizmu korporatyvnogho upravlinnja [Theoretical-methodological and conceptual principles of formation of organizational-economic mechanism of corporate governance]. Kharkiv: FOP Aleksandrova K. M.; $\mathrm{VD} \ll \mathrm{INZhEK}$. (in Ukrainian)

Shirjaeva, R. I. (2011). Institucional'noe obespechenie realizacii potenciala gosudarstvennoj sobstvennosti [Institutional support for the realization of state property potential]. Voprosy jekonomiki $i$ prava, 4, $154-158$. (in Russian)

Solovjan, Ju. (2011). Upravlinnja derzhavnymy korporatyvnymy pravamy: ocinka efektyvnosti [Management of state corporate rights: evaluation of efficiency]. Visnyk Kyjivsjkogho nacionaljnogho universytetu imeni Tarasa Shevchenka, 121-122, 103-108. Retrieved from: http://nbuv.gov.ua/UJRN/VKNU_Ekon_2011_121-122_30 (accessed 04 November 2019).

State Property Fund of Ukraine (2019). Rejestr korporatyvnykh prav derzhavy [Register of corporate rights of the state]. Retrieved from: http://www.spfu.gov.ua/ru/documents/docs-list/spf-management-Reestr-korporativnihprav.html?page $=27$ \&per-page $=10$ (accessed 04 November 2019).

Ticha, M. (2009). Property Rights and Economic Prosperity - An Institutional View. Proceedings from: The 7th International Conference on Economic Policy in the European Union Member Countries. Trojanovice, Czech Republic.

Tkachuk, O., \& Khachatryan, V. (2019). World spatial features of doing business. Baltic Journal of Economic Studies, vol. 5, no 2, pp. 234-241. doi: 10.30525/2256-0742/2019-5-2-234-241

Umantsiv, Iu., \& Ishchenko, O. (2017). Banking Sector and Economy of CEE Countries: Development Features and Correlation.Journal Of Settlements And Spatial Planning, vol. 8, no. 1, 59-70.

Vasilev, L. S. (1993). Istorija drevnego Vostoka [The history of Ancient East]. Moscow: Vysshaja shkola. (in Russian) Volchik, V. V. (2014). Institucional'nye podhody k issledovaniju sobstvennosti: vozmozhen li sintez? [Institutional Approaches to Property Research: Is Synthesis Possible?]. TERRA ECONOMICUS, 2(12), 22-33.

Zawojska, A., \& Siudek, T. (2013). Property Rights and Macroeconomic Performance in Central and Eastern European EU Member States. Proceedings from: International Scientific Conference on Economic Science for Rural Development. Latvia. Retrieved from: http://agris.fao.org/agris-search/search.do?recordID=LV2013000480 (accessed 04 November 2019).

Zvit pro robotu Fondu derzhavnogho majna Ukrajiny ta khid pryvatyzaciji derzhavnogho majna u 2017 roci (2018). [Report on the work of the State Property Fund of Ukraine and the progress of privatization of state property in 2017]. Kyiv: SPFU. (in Ukrainian) 